\title{
Reduced Acoustic Startle Response and Prepulse Inhibition in the Tg4-42 Model of Alzheimer's Disease
}

\author{
Marius E. Sichler, Maximilian J. Löw, Eva M. Schleicher, Thomas A. Bayer and Yvonne Bouter* \\ Division of Molecular Psychiatry, Department of Psychiatry and Psychotherapy, University Medical Center \\ Goettingen (UMG), Georg-August-University, Goettingen, Germany
}

Accepted 19 September 2019

\begin{abstract}
Sensorimotor deficits have been described in several neuropsychiatric disorders including Alzheimer's disease. The aim of the present study was to evaluate possible sensorimotor gating deficits in the $\mathrm{Tg} 4-42$ mouse model of Alzheimer's disease using the prepulse inhibition task (PPI). Previous studies indicated that the hippocampus is essentially involved in the regulation of PPI. We analyzed 7-month-old homozygous Tg4-42 mice as mice at this age display severe neuron loss especially in the CA1 region of the hippocampus. Our results revealed a reduced startle response and PPI in Tg4-42 mice. The observed deficits in startle response and PPI are likely due to altered sensory processing abilities rather than hearing deficits as Tg4-42 displayed intact hearing in the fear conditioning task. The present study demonstrates for the first time that sensorimotor gating is impaired in Tg4-42 mice. Analyzing startle response as well as the PPI may offer valuable measurements to assess the efficacy of therapeutic strategies in the future in this Alzheimer's disease model.
\end{abstract}

Keywords: Alzheimer's disease, cognitive deficits, fear conditioning, hippocampus, N-terminally truncated A $\beta$, neuron loss, prepulse inhibition, sensorimotor gating

\section{INTRODUCTION}

Alzheimer's disease (AD) is a neurodegenerative disease characterized by cognitive and memory deficits due to structural and functional abnormalities including amyloid- $\beta(A \beta)$ accumulation, neurofibrillary tangles and neuron loss [1-3].

Attention and executive function deficits as well as deficits in information processing are early characteristics of $\mathrm{AD}$ [4]. AD patients show a reduced attention span and are more prone to distractions due

\footnotetext{
*Correspondence to: Dr. Yvonne Bouter, Division of Molecular Psychiatry, Department of Psychiatry and Psychotherapy, University Medical Center Goettingen (UMG), Georg-AugustUniversity, Goettingen, Germany. E-mails: yvonne.bouter@ med.uni-goettingen.de, yvonne_bout@gmx.de
}

to impaired inhibitory mechanisms $[5,6]$. The lack of filtering out unnecessary, conflicting or redundant information, a process known as sensorimotor gating, is an aspect of selective attention that is affected early in the disease progression $[7,8]$.

Prepulse inhibition (PPI) is a test considered to mirror an organism's ability to filter out irrelevant information is used to assess attention deficits and sensorimotor gating. PPI refers to a reduction of the magnitude of the startle response when a stimulus (pulse) is preceded by a weaker stimulus (prepulse) $[9,10]$. While PPI does not require learning, it is modulated by higher cognitive processes and PPI deficits reflect sensorimotor gating impairments and the inability to filter out irrelevant information $[9,11$, 12]. Sensory gating deficits have been described in 
patients with mild and moderate $\mathrm{AD}$ and PPI has been discussed as a biomarker for early AD [13-15].

Acoustic startle response (ASR) is defined as a motor reaction to a loud and sudden acoustic signal and often measured in combination with PPI.

According to the amyloid cascade hypothesis, $A \beta$ depositions are the causative event in the pathology of $A D . A \beta$ is derived from the amyloid- $\beta$ protein precursor $(\mathrm{A} \beta \mathrm{PP})$ through enzymatic cleavage by $\beta$ - and $\gamma$-secretases [16]. Next to full-length $A \beta$ starting with an aspartate at the first amino acid, a variety of truncated and modified $A \beta$ species have been identified in AD. N-terminal truncated $A \beta$ peptides are very abundant in the brains of familial and sporadic AD patients and there is substantial evidence that $\mathrm{N}$-terminal truncated $\mathrm{A} \beta$ variants play a key role in the disease. Furthermore, $\mathrm{N}$-terminal deletion enhances $A \beta$ aggregation and neurotoxicity [17-19]. Thereby $A \beta_{4-42}$ is a particular abundant species and one of the major fractions identified in the hippocampus and cortex of AD patients [20,21]. The transgenic mouse model Tg4-42 expresses exclusively human $\mathrm{N}$-terminally truncated $\mathrm{A} \beta_{4-42}$ albeit without human A $\beta P P$ overexpression [22]. Tg4-42 mice show intraneuronal $A \beta$ accumulation accompanied with astro- and microgliosis predominantly in the hippocampus [22]. In addition, $\mathrm{Tg} 4-42$ mice develop age-dependent behavior and memory deficits albeit without plaque formation [22, 23]. Furthermore, Tg4-42 mice display age-dependent motor deficits as well as an altered glucose metabolism accompanied with severe neuron loss [22-24].

In addition to $A \beta$ plaques and neurofibrillary tangles, neuron loss is a main pathological hallmark of $\mathrm{AD}$ and cortical atrophy the most evident macroscopic characteristic of AD. [3]. Atrophy affects next to the amygdale and entorhinal cortex mainly the hippocampus $[25,26]$. While the hippocampus is essential for the formation of memory and learning it has also been linked to sensorimotor processes. PPI, as a test for sensorimotor gating, is highly affected by the hippocampus [27]. It has been shown in different animal studies that alterations of the hippocampus lead to an impaired PPI [27-29]. Furthermore, hippocampal lesion and microinfusion studies demonstrated that the hippocampus plays a crucial role in regulating startle reactivity and PPI [29].

The aim of the current study was to extend previous findings on the Tg4-42 model by examining sensorimotor gating and acoustic startle response in aged Tg4-42 mice. Furthermore, we discuss the results in the context of other, well-studied AD models.

\section{MATERIAL AND METHODS}

\section{Tg4-42 transgenic mice}

The generation of $\mathrm{Tg} 4-42$ mice has been described previously [22]. Briefly, Tg4-42 mice express human $\mathrm{A} \beta_{4-42}$ fused to the murine thyrotropin-releasing hormone signal peptide under the control of the neuronal Thy-1 promoter. Tg4-42 mice are kept on a C57B1/6J genetic background. Homozygous 7month-old ( \pm 10 days) Tg4-42 and wildtype (WT) control mice (C57Bl/6J, Jackson Laboratories, Bar Harbor, ME, USA) were used in this study with an equal distribution of male and female animals $(n=11-13)$. No sex-differences were detected in any of the experiments. Mice used for the PPI study were part of a longer study and got injected intraperitoneal with a solution of $5 \%$ Tween 80 in $0,9 \%$ sodium chloride daily for 6 weeks, starting at 3 months. Tween- 80 is commonly used as a vehicle to evaluate the behavioral effects of experimental drugs without apparent adverse side effects [30-38]. All animals were handled according to the guidelines of the 'Society for Laboratory Animals Science' (GV-SOLAS) and the guidelines of the 'Federation of European Laboratory Animal Science Association' (FELASA). Furthermore, all experiments were approved by the 'Lower Saxony State Office for Consumer Protection and Food Safety' (LAVES). All efforts were made to minimize suffering and the number of animals used for this study.

\section{Acoustic startle response and prepulse inhibition}

Tg4-42 $(n=12)$ and WT $(n=13)$ animals were placed individually in a metal grid cage $(90 \times 40 \times 40 \mathrm{~mm})$ to restrict exploratory behavior and major movements. The cage was equipped with a movable platform floor attached to a sensor recording vertical movements (Process Control 25200 series, TSE GmbH, Germany). The cage was placed in a sound-attenuating isolation cabinet (TSE GmbH, Germany). Each experimental session started with a 3-min habituation period to $65 \mathrm{~dB}$ background white noise followed by a 2-min baseline recording. Loudspeakers were used to induce startle reflexes by acoustic stimuli. A startle reaction to an acoustic stimulus including body muscle contractions and jumping causes movement of the platform. A transient force resulting from this movement was 
recorded during a time window of $100 \mathrm{~ms}$ beginning with the onset of the acoustic stimulus.

Six pulse-alone trials using startle stimuli of $120 \mathrm{~dB}$ and $40 \mathrm{~ms}$ were applied after the baseline recording. PPI was tested applying the $120 \mathrm{~dB} 40 \mathrm{~ms}$ startle pulse alone or preceded by a prepulse $20 \mathrm{~ms}$ stimulus of 70,75 , or $80 \mathrm{~dB}$. An interval of $100 \mathrm{~ms}$ with background noise was applied between each prepulse and pulse stimulus. A total of 30 trials with 10 trials of startle response alone, no stimulus trials and pulse preceded by a 70,75 , or $80 \mathrm{~dB}(2000 \mathrm{~Hz}$ frequency) prepulse were applied in a pseudorandom order with inter-trial intervals from 8 to $22 \mathrm{~s}$. Maximum amplitudes for all types of trials were averaged for every mouse. Startle Response/PPI software Version 03.05 was used (TSE GmbH, Germany) and PPI at each sound level was calculated using the following formula:

$$
\text { Prepulse inhibition }[\%]=\left(1-\frac{\text { average startle amplitude afterprepulse and pulse }}{\text { average startle amplitude after pulse alone }} * 100\right)
$$

\section{Contextual and tone fear conditioning}

An additional naive group of 7-month-old Tg4-42 $(n=12)$ and same-aged WT animals $(n=10)$ were subjected to a 3-day delay fear conditioning protocol as previously described [17]. Briefly, on the first day mice were allowed to explore a condition chamber (Ugo Basile, Italy) with black and white checkered walls and a steel grid for $150 \mathrm{~s}$. Baseline freezing was measured during this habituation period using ANY-Maze video tracking software (Stoelting Co, USA). A tone $(2000 \mathrm{~Hz}, 80 \mathrm{~dB})$ was presented for $30 \mathrm{~s}$ that ended simultaneously with a 2 -s foot-shock $(0.7 \mathrm{~mA})$. In order to test contextual memory mice were placed $24 \mathrm{~h}$ later in the same chamber for $210 \mathrm{~s}$ while freezing behavior was recorded. To test for tone fear conditioning $48 \mathrm{~h}$ later mice were placed back into the chamber now covered with white walls. Furthermore, an acetic acid scent was used to clean the chamber to create a new scent. After $150 \mathrm{~s}$ of baseline recording the same tone as in the fear conditioning trial was presented for $30 \mathrm{~s}$ without a following footshock. Freezing behavior was recorded before and during the tone.

\section{Quantification of neuron numbers using unbiased stereology}

Unbiased stereology was used to quantify the number of neurons in the hippocampal cell layer CA1 of 7-month-old mice ( $n=10$ per genotype) as previ-

\section{Statistical analysis} (GraphPad, USA).

\section{RESULTS}

Decreased acoustic startle response in Tg4-42 mice $\mathrm{F}(12,10)=1.425, p<0.001)$. ously described [22]. Briefly, mice were anesthetized and transcardially perfused with $4 \%$ paraformaldehyde. Left brain hemispheres were fixed in $4 \%$ paraformaldehyde, cryoprotected in $30 \%$ sucrose, frozen and frontally cut into a series of $30-\mu \mathrm{m}$ thick sections on a cryostat (Microm HM550, Germany). Every tenth section was systematically sampled and stained with cresyl violet. Stereological analysis of the hippocampal cell layer CA1 (Bregma -1.22 to $-3.80 \mathrm{~mm}$ ) was performed $\mathrm{Tg} 4-42$ and WT mice using a stereology workstation (Olympus BX51 with a motorized specimen stage for automatic sampling, StereoInvestigator 7 [MicroBrightField, Williston, VT, USA]). The volume of the CA1 region was estimated by using Cavalieri's principle [39].

Differences between groups were tested with unpaired $t$-test, one-way analysis of variance (ANOVA) or two-way analysis of variance (ANOVA) followed by Bonferroni multiple comparisons as indicated. Possible outliers were determined using the GraphPad outlier function. All data are given as means \pm standard error of the mean (SEM). Significance levels are given as follows: $* * * p<0.001$; ${ }^{* *} p<0.01 ; * p<0.05$. All statistics were calculated using GraphPad Prism version 6.07 for Windows

The acoustic startle response (ASR) to the startle stimulus alone was measured in Tg4-42 and WT animals. Tg4-42 mice showed a significantly reduced startle response compared to same-aged WT mice (Fig. 1A; unpaired $t$-test: $\mathrm{F}(12,10)=8.148, p<0.01$ ). Furthermore, the latency to startle was significantly increased in Tg4-42 animals (Fig. 1B; unpaired $t$-test: 


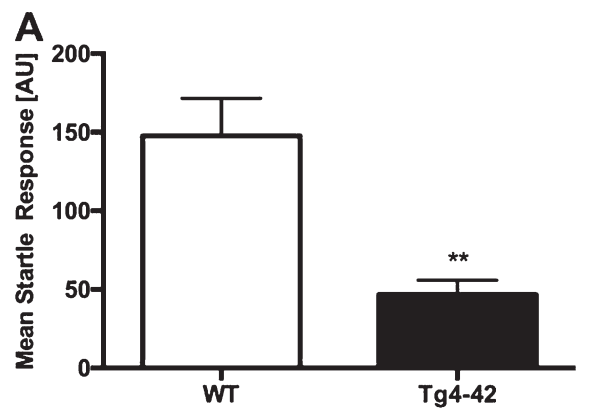

B
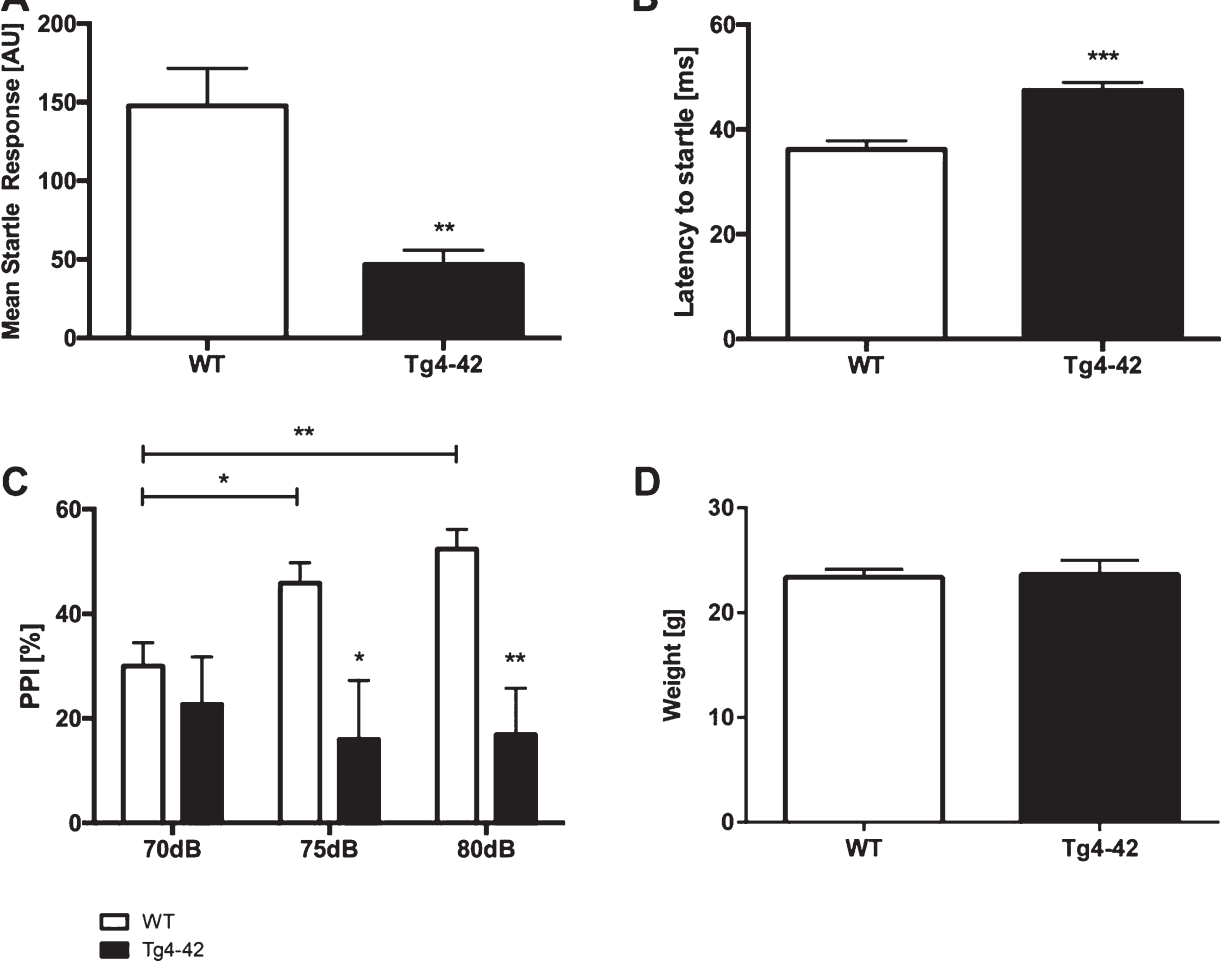

Fig. 1. Altered acoustic startle response and prepulse inhibition in $\mathrm{Tg} 4-42$ mice. $\mathrm{Tg} 4-42$ mice showed a significantly lower acoustic startle response (A) and an increased latency to startle (B). Prepulse inhibition (PPI\%) was significantly lower in Tg4-42 $(n=11)$ compared to WT $(n=13)$ mice at 70,75, and $80 \mathrm{~dB}(\mathrm{C})$. Body weight did not differ between WT and Tg4-42 mice (D). AU = Arbitrary unit. Data presented as mean \pm S.E.M. A-B, D) unpaired $t$-test. C) Two-way analysis of variance (ANOVA) followed by Bonferroni multiple comparisons. $* * * p<0.001 ; * * p<0.01 ; * p<0.05$.

\section{Impaired prepulse inhibition in Tg4-42 mice}

PPI was performed to analyze sensorimotor gating. Tg4-42 mice displayed a significantly lower PPI compared to same-aged WT animals at 70, 75, and $80 \mathrm{~dB}$ (Fig. 1 C; two-way-ANOVA, main effect of genotype: $\mathrm{F}(1,22)=12.05, p<0.01)$. Louder prepulse tones did increase PPI in WT but not in Tg4-42 animals (Fig. $1 \mathrm{C}$; two-way-ANOVA, main effect of stimulus intensity: WT: $\mathrm{F}(2,36)=8.017, p<0.01$; Tg4-42: $\mathrm{F}(2,30)=0.1378, p>0.05)$. In addition, the weight of WT and Tg4-42 mice did not differ (Fig. 1D, unpaired $t$-test: $\mathrm{F}(15,13)=2.443, p>0.05)$.

\section{Decreased contextual learning in Tg4-42 mice}

WT and Tg4-42 mice showed similar degrees of freezing in the training session of the fear conditioning experiment (Fig. 2A; one-way-ANOVA, training trial: $\mathrm{F}(3,42)=8.267, p>0.05)$. However, when tested for context fear conditioning only WT mice demonstrated significantly increased freezing behavior
(Fig. 2A; one-way-ANOVA, WT: $\mathrm{F}(3,42)=8.267$, $p<0.001$; $\mathrm{Tg} 4-42: \mathrm{F}(3,42)=8.267, p>0.05) . \mathrm{Tg} 4-42$ showed impaired contextual learning as they did not associate the foot-shock during the training session with the chamber. It has to be noted that Tg442 animals showed normal pain perception as they vocalized and jumped in response to the electric footshock similar to WT mice.

When tested for conditioned fear of a tone Tg4-42 and WT mice exhibited similar degrees of freezing as response to the tone (Fig. 2B; one-way-ANOVA, $W T$ : $\mathrm{F}(3,42)=24.36, p<0.001 ; T g 4-42: \mathrm{F}(3,42)=24.36$, $p<0.001)$.

\section{Pronounced neuron loss in the hippocampus of Tg4-42 mice}

Unbiased design-based Stereology revealed a $55 \%$ neuron loss in 7-month-old $\mathrm{Tg} 4-42$ mice in the CA1 layer of the hippocampus compared to same-aged WT animals (Fig. 3A; unpaired $t$ test: $\mathrm{F}(9,9)=1.343, p<0.001$; neuron number WT: mean $=286708 \pm 7670$; neuron number $\mathrm{Tg} 4-42$ : 
A

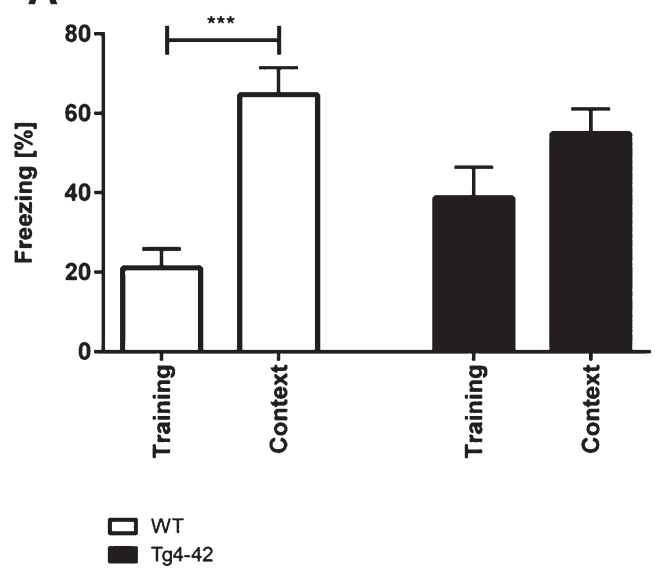

B

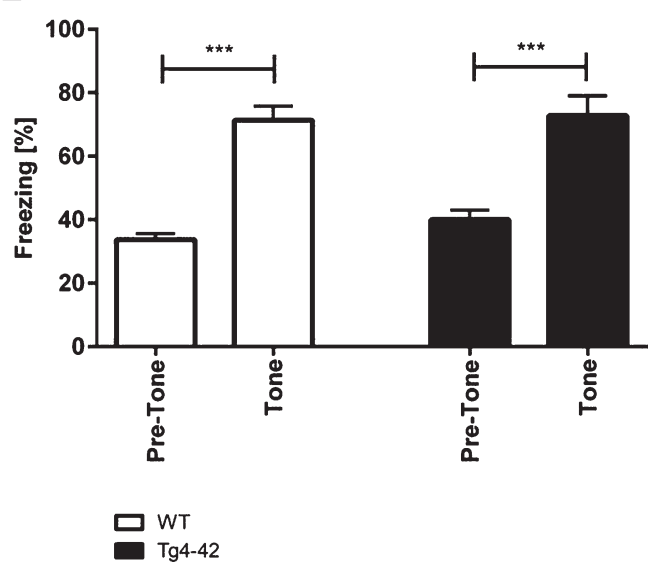

Fig. 2. Impaired contextual conditioning in Tg4-42 mice. Tg4-42 and WT mice were trained in a contextual (A) and tone fear (B) conditioning task $(n=10-12)$. During the initial training session involving a tone-foot-shock pairing, WT and $\mathrm{Tg} 4-42$ mice displayed comparable degrees of freezing (A). Animals were reintroduced to the original training context 24 hours post training and tested for contextual memory. WT shock froze significantly more during re-exposure to the context compared to the training trial. In contrast, $\mathrm{Tg} 4-42$ mice did not associate the context with the received foot-shock as freezing was not significantly different between the training and the tone trial (A). Mice were placed in an altered fear conditioning chamber 48 hours post training and tested for freezing during tone presentation. WT and Tg4-42 mice showed a significant increase on freezing response to the tone presentation (B). Data presented as mean \pm S.E.M. One-way analysis of variance (ANOVA) followed by Bonferroni multiple comparisons. $* * * p<0.001$.

mean $=129713 \pm 6619)$. Furthermore, analysis of the CA1 volume demonstrated a significant volume reduction of $26 \%$ in $\mathrm{Tg} 4-42$ mice (Fig. 3B; unpaired $t$-test: $\mathrm{F}(9,9)=1.097, p<0.05)$.

\section{DISCUSSION}

Acoustic startle response (ASR) is a protective response and defined as a motor reaction to a loud and sudden acoustic signal. While ASR in humans is mainly quantified using eye-blink reflexes, startle response in rodents is assessed through whole body reflexes [40-42]. Here we demonstrated that Tg4-42 mice showed a reduced startle response and an increased latency to startle. Interestingly, ASR seems to highly vary between different mouse models for AD. Mouse models of AD have shown unaltered, decreased as well as increased startle responses (Table 1). In line with our findings 5XFAD mice and Tau P301 S mice displayed reduced ASR [43-45]. In contrast, APOE knock-out and 3xTg mice showed an increased startle response [46, 47]. Several AD models including J20 and APP/PS1 also displayed an unaltered startle response [48-50].

While ASR studies in AD patients are limited, Salem et al. (2001) [51] described an increased latency to peak startle response with increasing white matter hyperintensities that are highly associated with AD [52-54].
Analyzing ASR in Tg4-42 mice may offer a valuable measurement when assessing the efficacy of therapeutic strategies in this mouse model. Assessing startle response is a sensitive, non-invasive, reproducible, reliable and easy measure that can even be studied without analyzing PPI [13].

Sensorimotor gating can be measured using PPI, a method that can be studied with similar procedures in humans and rodents and reflects the ability to exclude sensory information from processing [55]. Reduced PPI reflects a dysfunction of sensorimotor gating and has been reported in several psychiatric and neurological disorders, including schizophrenia, post-traumatic stress, bipolar disorders, Huntington's disease as well as $\operatorname{AD}[11,14$, 56-59].

Interestingly, a large-scale meta-analysis from more than $1300 \mathrm{C} 57 \mathrm{BL} / 6 \mathrm{~J}$ male mice showed that there is no simple linear relationship between ASR and PPI levels [60]. In line with these findings, reduced PPI has been described in AD mice with an unaltered [48-50], reduced [43, 44], and increased startle response [47].

Tg4-42 mice demonstrated impairments of sensorimotor gating as PPI was significantly lower in transgenic mice compared to WT animals. Similar PPI deficits were reported in several $\mathrm{AD}$ lines including J20, TBA2.1, APP/PS1, and 3xTg AD mice (Table 1). 

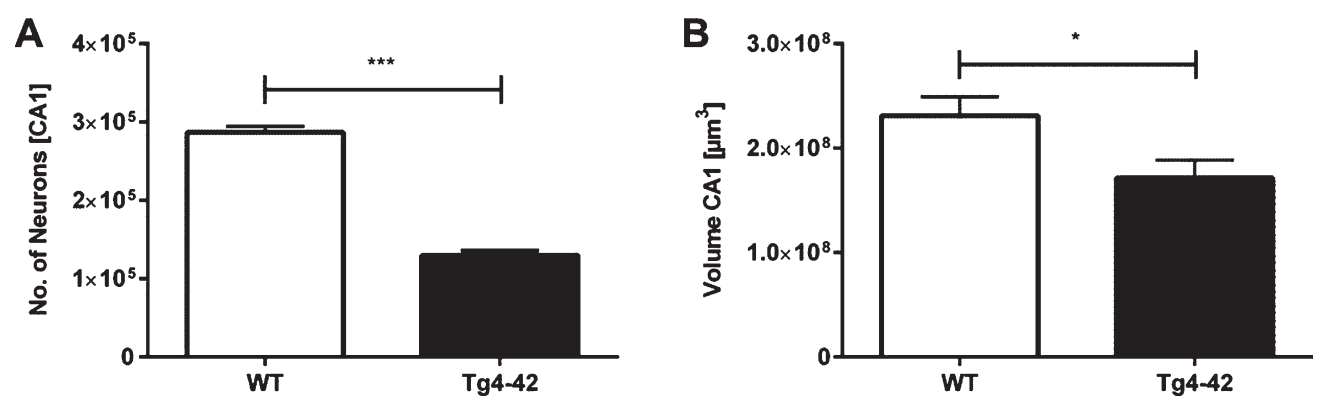

Fig. 3. Neuron loss in the CA1 pyramidal cell layer of the hippocampus in Tg4-42 mice. Tg4-42 mice showed a significant neuron loss of $55 \%$ in the CA1 region (A). Furthermore, Tg4-42 mice displayed a $26 \%$ volume reduction in the CA1 region of the hippocampus (B). Data presented as mean \pm S.E.M. unpaired $t$-test. $* * * p<0.001 ; * p<0.05$.

In line with our finding, Ueki et al. (2006) [14] reported sensorimotor gating deficits in patients with mild AD using PPI. In a recent study, PPI confirmed sensorimotor gating deficits in early AD cases [13]. However, another PPI study did not report differences between AD patients and healthy controls [61]. The inconsistent PPI results in AD patients are likely due to different study protocols and disease stages.

Previous studies indicate that the hippocampus is essentially involved in the regulation of PPI [27-29, 62]. Some of the earliest damages in AD brains have been reported in the hippocampus and Padurariu et al. (2012) reported a decrease in neuronal density particularly in the CA1 region of the hippocampus in $\mathrm{AD}$ patients [63]. Consistent with these results, $\mathrm{Tg} 4-$ 42 mice showed a neuron loss of more than $50 \%$ in the CA1 region of the hippocampus at 7 months of age. It has been demonstrated that hippocampal lesions induce disruptions of PPI in rodents [27, 64]. In line with our findings Caine and colleagues (1992) examined the relationship between PPI and the hippocampus and showed that modulations of the CA1 reduced the acoustic startle reflex and PPI in rats [28].

ASR and PPI can among others be affected by housing conditions, the genetic background strain, weight and hearing ability [65-69].

Weight can severely influence the outcome of behavior studies. Fodor et al. (2016) demonstrated that lower body weight in rats resulted in a reduced ASR, while body weight did not affect PPI [68]. Therefore, the animal's weight should always be taken into consideration especially when analyzing startle response in rodents. However, the observed reduced ASR in Tg4-42 cannot be attributed to an altered body weight as the weight of transgenic mice was comparable to wildtype animals.

Willot et al. (2003) analyzed the correlation between acoustic startle response, PPI, and auditory abilities in forty inbred mouse strains and concluded that a severe hearing loss is necessary to influence PPI [65]. O'Leary et al. (2017) reported an agedependent hearing dysfunction in 5XFAD mice and attributed the decreased startle response at least partially to the observed hearing loss [44]. In contrast, Story et al. (2018) argued that the decreased startle response observed in 5XFAD cannot be attributed to hearing deficits as 5XFAD mice show a response to the startle tone [43].

The altered startle response and impaired PPI in Tg4-42 mice might also be explained by possible hearing dysfunctions. If $\mathrm{Tg} 4-42$ mice display hearing impairments, then it could be argued that difficulties in detecting the prepulse could explain the impaired ASR and PPI. However, there is no evidence that Tg4-42 mice display any hearing deficits. Although Tg4-42 mice showed a decreased ASR they did respond to the $120 \mathrm{~dB}$ startle tone. In addition, Tg4-42 mice reacted to the $80 \mathrm{~dB}$ tone presented in the fear conditioning experiment similar to wildtype animals.

While Tg4-42 mice showed learning deficits in the contextual fear condition task, they displayed no impairments in conditioned learning in response to the tone stimulus. Homozygous Tg4-42 mice in this study exhibit a selective impairment of contextual fear learning while their tone learning ability remains intact similar to the results previously described in 12-month-old hemizygous Tg4-42 mice [70]. These results indicate that Tg4-42 mice exhibit a selective impairment of contextual fear learning while their tone learning ability remains intact. Therefore, the observed deficits in startle response and PPI are likely due to altered sensory processing abilities rather than hearing deficits. However, further studies are needed to assess hearing in $\mathrm{Tg} 4-42$ mice and determine the contribution of possible reduced auditory thresholds 
Table 1

Acoustic startle response and prepulse inhibition in different mouse models related to the Alzheimer's disease pathology

\begin{tabular}{|c|c|c|c|c|c|c|}
\hline Mouse model & Transgene/mutations & Test age & Methodology & ASR & PPI [\%] & Reference \\
\hline $\operatorname{Tg} 4-42$ & $\mathrm{~A} \beta_{4-42}$ & $7 \mathrm{~m}$ & $\begin{array}{l}\text { Background: } 65 \mathrm{~dB} \\
\text { Startle pulse: } 120 \mathrm{~dB} \text {; } \\
\quad 40 \mathrm{~ms} \\
\text { Prepulse: } 70,75 \text {, } \\
\quad 80 \mathrm{~dB}, 20 \mathrm{~ms}\end{array}$ & $\downarrow$ & $\downarrow$ & Current study \\
\hline TBA2.1 & Pyroglutamate $A \beta_{3-42}$ & 1) $1 \mathrm{~m}$ & $\begin{array}{l}\text { Background: } 68 \mathrm{~dB} \\
\text { Startle pulse: } 120 \mathrm{~dB} \text {, } \\
20 \mathrm{~ms} \\
\text { Prepulse: } 72,76,80 \text {, } \\
84 \mathrm{~dB}, 20 \mathrm{~ms}\end{array}$ & NIA & $\downarrow$ & [71] \\
\hline $\mathrm{J} 20$ & $\begin{array}{l}\mathrm{APP}_{\mathrm{K} 670 / \mathrm{M} 671 \mathrm{~L}} \\
\mathrm{APP}_{\mathrm{V} 717 \mathrm{~F}}\end{array}$ & $\begin{array}{l}\text { 1) } 10-2 \mathrm{~m} \\
\text { 2) } 21-23 \mathrm{~m}\end{array}$ & $\begin{array}{l}\text { Background: } 65 \mathrm{~dB} \text {; } \\
\text { Startle pulse: } 120 \mathrm{~dB} \text {, } \\
\quad 40 \mathrm{~ms} \\
\text { Prepulse: } 69,73 \text {, } \\
\quad 81 \mathrm{~dB}, 40 \mathrm{~ms}\end{array}$ & ns & $\begin{array}{l}\text { 1) } \downarrow \\
\text { 2) } \downarrow\end{array}$ & [48] \\
\hline$\overline{\mathrm{APP} / \mathrm{PS} 1}$ & $\begin{array}{l}\text { APP }_{\mathrm{KM} 670 \mathrm{~N} / \mathrm{M} 671 \mathrm{~N}} \\
\text { PSEN1 } \\
\mathrm{M} 146 \mathrm{~L}\end{array}$ & $\begin{array}{l}\text { 1) } 3 \mathrm{~m} \\
\text { 2) } 7 \mathrm{~m} \\
\text { 3) } 22 \mathrm{~m}\end{array}$ & $\begin{array}{l}\text { Background: } 70 \mathrm{~dB} \text {; } \\
\text { Startle pulse: } 120 \mathrm{~dB} \text {, } \\
\quad 40 \mathrm{~ms} ; \\
\text { Prepulse: } 73,76 \text {, } \\
\quad 82 \mathrm{~dB}, 20 \mathrm{~ms}\end{array}$ & ns & $\begin{array}{l}\text { 1) } \mathrm{ns} \\
\text { 2) } \downarrow \\
\text { 3) } \downarrow\end{array}$ & [49] \\
\hline APP/PS1 & $\begin{array}{l}\text { APP }_{\mathrm{K} 670 \mathrm{~N} / \mathrm{M} 671 \mathrm{~N}} \\
\mathrm{PSEN} 1_{\mathrm{M} 146 \mathrm{~L}}\end{array}$ & $12 \mathrm{~m}$ & $\begin{array}{l}\text { Background: } 70 \mathrm{~dB} \\
\text { Startle pulse: } 125 \mathrm{~dB} \text {, } \\
40 \mathrm{~ms} \\
\text { Prepulse: } 75,80,85 \text {, } \\
90,95 \mathrm{~dB}, 20 \mathrm{~ms}\end{array}$ & $\mathrm{~ns}$ & ns & {$[50]$} \\
\hline $5 \mathrm{xFAD}$ & $\begin{array}{l}\text { APP }_{\mathrm{KM} 670 / 671 \mathrm{NL}} \\
\text { APP }_{1716 \mathrm{~V}} \\
\text { APP }_{\mathrm{V} 717 \mathrm{I}} \\
\text { PSEN1 }_{\mathrm{M} 146 \mathrm{~L}} \\
\text { PSEN1 }_{\mathrm{L} 286 \mathrm{~V}}\end{array}$ & $8 \mathrm{~m}$ & $\begin{array}{l}\text { Background: } 65 \mathrm{~dB} \text {; } \\
\text { Startle pulse: } 120 \mathrm{~dB} \text {, } \\
50 \mathrm{~ms} \\
\text { Prepulse: } 73,81 \mathrm{~dB} \text {, } \\
30 \mathrm{~ms}\end{array}$ & $\downarrow$ & $\downarrow$ & {$[43]$} \\
\hline $5 \mathrm{xFAD}$ & $\begin{array}{l}\text { APP }_{\mathrm{KM} 670 / 671 \mathrm{NL}}, \\
\text { APP }_{1716 \mathrm{~V}}, \\
\text { APP }_{\mathrm{V} 717 \mathrm{I}}, \\
\text { PSEN1 }_{\mathrm{M} 146 \mathrm{~L}}, \\
\text { PSEN1 }_{\mathrm{L} 286 \mathrm{~V}}\end{array}$ & $\begin{array}{l}\text { 1) } 3-4 \mathrm{~m} \\
\text { 2) } 7 \mathrm{~m} \\
\text { 4) } 13 \mathrm{~m} \\
\text { 5) } 16 \mathrm{~m} \\
\text { 3) } 10 \mathrm{~m} \\
\end{array}$ & $\begin{array}{l}\text { Background: } 70 \mathrm{~dB} \text {; } \\
\text { Startle pulse: } 120 \mathrm{~dB} \text {, } \\
\quad 40 \mathrm{~ms} \\
\text { Prepulse: } 74,78, \\
82,86,90 \mathrm{~dB}, 20 \mathrm{~ms}\end{array}$ & $\downarrow$ & $\begin{array}{l}\text { 1) ns } \\
\text { 2) }-5 \text { ) NIA }\end{array}$ & [44] \\
\hline $3 \times \mathrm{xg}$ & $\begin{array}{l}\text { APP }_{\mathrm{KM} 670 / 671 \mathrm{NL}}, \\
\text { MAPT }_{\mathrm{P} 30 \mathrm{IL}} \\
\text { PSEN1 }_{\mathrm{M} 146 \mathrm{~V}}\end{array}$ & $7 \mathrm{~m}$ & $\begin{array}{l}\text { Background: } 70 \mathrm{~dB} \\
\text { Startle pulse: } \\
125 \mathrm{~dB}, 100 \mathrm{~ms} ; \\
\text { Prepulse: } 85 \mathrm{~dB} \text {, } \\
50 \mathrm{~ms} \\
\end{array}$ & $\uparrow$ & $\downarrow$ & {$[47]$} \\
\hline $\begin{array}{l}\text { Tau P301 S } \\
\text { (Line PS19) }\end{array}$ & P301S, 1N4R & $3 \mathrm{~m}$ & $\begin{array}{l}\text { Background: } 70 \mathrm{~dB} \\
\text { Startle pulse: } 110 \mathrm{~dB} \text {, } \\
120 \mathrm{~dB}, 40 \mathrm{~ms} \\
\text { Prepulse: } 74,78 \mathrm{~dB}\end{array}$ & $\downarrow$ & $\uparrow$ & [45] \\
\hline $\begin{array}{l}\text { 1) GFAP- } \\
\text { APOE3/APOE } \\
\text { Knock-out } \\
\end{array}$ & APOE3/APOE4 & $6 \mathrm{~m}$ & Background: $65 \mathrm{~dB}$ & 1) $\mathrm{ns}$ & 1) -3$) \mathrm{ns}$ & [46] \\
\hline $\begin{array}{l}\text { 2) GFAP- } \\
\text { APOE4/APOE } \\
\text { Knock-out }\end{array}$ & & & $\begin{array}{l}\text { Startle pulse: } 120 \mathrm{~dB} \\
\quad 40 \mathrm{~ms}\end{array}$ & 2) - & & \\
\hline 3) APOE Knock-out & & & $\begin{array}{c}\text { Prepulse: } 69,77 \text {, } \\
85 \mathrm{~dB}, 20 \mathrm{~ms}\end{array}$ & 3) $\uparrow$ & & \\
\hline
\end{tabular}

ASR, acoustic startle response; PPI, prepulse inhibition; ns, not significant; NIA, no information available. 
and non-auditory phenotypes on the acoustic startle response and impaired PPI.

The variability in experimental procedures between the tested $\mathrm{AD}$ models is compared to other behavior experiments rather small. The startle impulse used in different studies differed between $110 \mathrm{~dB}$ and $125 \mathrm{~dB}$. The used prepulse tones ranged from $73 \mathrm{~dB}$ to $95 \mathrm{~dB}$ and the majority of studies used multiple prepulse tones with at least a $10 \mathrm{~dB}$ difference between the lowest and highest tone (Table 1). However, these varieties need to be taken into consideration when comparing different $\mathrm{AD}$ mouse lines.

Taken together, the present study demonstrates for the first time that sensorimotor gating is impaired in Tg4-42 mice at a disease stage where mice display significant neuron loss and memory deficits. Therefore, analysis of startle response and PPI offer a useful additional tool to measure therapeutic efficacy in Tg4-42 mice.

\section{ACKNOWLEDGMENTS}

This work was supported by the German Research Foundation (CNMPB) and the 'Alzheimer Stiftung Göttingen' to YB. This study was also supported by the Jacob-Henle-Program for Experimental Medicine of the University Medicine Goettingen to MJL. MES is supported by Helios Kliniken GmbH. We acknowledge support by the Open Access Publication Funds of the Göttingen University.

\section{CONFLICT OF INTEREST}

The Tg-4-42 mouse model has been patented by the University Medicine Göttingen and TAB.

\section{REFERENCES}

[1] Tarawneh R, Holtzman DM (2012) The clinical problem of symptomatic Alzheimer disease and mild cognitive impairment. Cold Spring Harb Perspect Med 2, a006148.

[2] Holtzman DM, Mandelkow E, Selkoe DJ (2012) Alzheimer disease in 2020. Cold Spring Harb Perspect Med 2, a011585.

[3] Holtzman DM, Morris JC, Goate AM (2011) Alzheimer's disease: the challenge of the second century. Sci Transl Med 3, $77 \mathrm{sr} 71$.

[4] Krinsky-McHale SJ, Devenny DA, Kittler P, Silverman W (2008) Selective attention deficits associated with mild cognitive impairment and early stage Alzheimer's disease in adults with Down syndrome. Am J Ment Retard 113, 369386.
[5] Perry RJ, Hodges JR (1999) Attention and executive deficits in Alzheimer's disease. A critical review. Brain 122 (Pt 3), 383-404.

[6] Pignatti R, Rabuffetti M, Imbornone E, Mantovani F, Alberoni M, Farina E, Canal N (2005) Specific impairments of selective attention in mild Alzheimer's disease. J Clin Exp Neuropsychol 27, 436-448.

[7] Levinoff EJ, Li KZ, Murtha S, Chertkow H (2004) Selective attention impairments in Alzheimer's disease: evidence for dissociable components. Neuropsychology 18, 580588.

[8] Ellwanger J, Geyer MA, Braff DL (2003) The relationship of age to prepulse inhibition and habituation of the acoustic startle response. Biol Psychol 62, 175-195.

[9] Peleg-Raibstein D, Philipp S, Feldon J, Yee BK (2015) Individual difference in prepulse inhibition does not predict spatial learning and memory performance in C57BL/6 mice. Cogn Affect Behav Neurosci 15, 878-888.

[10] Graham FK (1975) Presidential Address, 1974. The more or less startling effects of weak prestimulation. Psychophysiology 12, 238-248.

[11] Braff DL, Geyer MA, Swerdlow NR (2001) Human studies of prepulse inhibition of startle: normal subjects, patient groups, and pharmacological studies. Psychopharmacology (Berl) 156, 234-258.

[12] Swerdlow NR, Geyer MA, Braff DL (2001) Neural circuit regulation of prepulse inhibition of startle in the rat: current knowledge and future challenges. Psychopharmacology (Berl) 156, 194-215.

[13] Schleicher EM, Ott FW, Muller M, Silcher B, Sichler ME, Low MJ, Wagner JM, Bouter Y (2019) Prolonged cannabidiol treatment lacks on detrimental effects on memory, motor performance and anxiety in C57BL/6J mice. Front Behav Neurosci 13, 94.

[14] Ueki A, Goto K, Sato N, Iso H, Morita Y (2006) Prepulse inhibition of acoustic startle response in mild cognitive impairment and mild dementia of Alzheimer type. Psychiatry Clin Neurosci 60, 55-62.

[15] Ally BA, Jones GE, Cole JA, Budson AE (2006) Sensory gating in patients with Alzheimer's disease and their biological children. Am J Alzheimers Dis Other Demen 21, 439-447.

[16] Zhang YW, Thompson R, Zhang H, Xu H (2011) APP processing in Alzheimer's disease. Mol Brain 4, 3.

[17] Pike CJ, Overman MJ, Cotman CW (1995) Amino-terminal deletions enhance aggregation of beta-amyloid peptides in vitro. J Biol Chem 270, 23895-23898.

[18] Bayer TA, Wirths O (2014) Focusing the amyloid cascade hypothesis on N-truncated Abeta peptides as drug targets against Alzheimer's disease. Acta Neuropathol 127, 787801.

[19] Dunys J, Valverde A, Checler F (2018) Are N- and C-terminally truncated Abeta species key pathological triggers in Alzheimer's disease? J Biol Chem 293, 1541915428.

[20] Masters CL, Multhaup G, Simms G, Pottgiesser J, Martins RN, Beyreuther K (1985) Neuronal origin of a cerebral amyloid: neurofibrillary tangles of Alzheimer's disease contain the same protein as the amyloid of plaque cores and blood vessels. EMBO J 4, 2757-2763.

[21] Portelius E, Bogdanovic N, Gustavsson MK, Volkmann I, Brinkmalm G, Zetterberg H, Winblad B, Blennow K (2010) Mass spectrometric characterization of brain amyloid beta isoform signatures in familial and sporadic Alzheimer's disease. Acta Neuropathol 120, 185-193. 
[22] Bouter Y, Dietrich K, Wittnam JL, Rezaei-Ghaleh N, Pillot T, Papot-Couturier S, Lefebvre T, Sprenger F, Wirths O, Zweckstetter M, Bayer TA (2013) N-truncated amyloid beta (Abeta) 4-42 forms stable aggregates and induces acute and long-lasting behavioral deficits. Acta Neuropathol 126, 189205.

[23] Bouter C, Henniges P, Franke TN, Irwin C, Sahlmann CO, Sichler ME, Beindorff N, Bayer TA, Bouter Y (2018) (18)FFDG-PET detects drastic changes in brain metabolism in the Tg4-42 model of Alzheimer's disease. Front Aging Neurosci 10, 425 .

[24] Wagner JM, Sichler ME, Schleicher EM, Franke TN, Irwin C, Low MJ, Beindorff N, Bouter C, Bayer TA, Bouter Y (2019) Analysis of motor function in the Tg4-42 mouse model of Alzheimer's disease. Front Behav Neurosci 13, 107.

[25] Halliday G (2017) Pathology and hippocampal atrophy in Alzheimer's disease. Lancet Neurol 16, 862-864.

[26] Bottino CM, Castro CC, Gomes RL, Buchpiguel CA, Marchetti RL, Neto MR (2002) Volumetric MRI measurements can differentiate Alzheimer's disease, mild cognitive impairment, and normal aging. Int Psychogeriatr 14, 59-72.

[27] Pouzet B, Feldon J, Veenman CL, Yee BK, Richmond M, Nicholas J, Rawlins P, Weiner I (1999) The effects of hippocampal and fimbria-fornix lesions on prepulse inhibition. Behav Neurosci 113, 968-981.

[28] Caine SB, Geyer MA, Swerdlow NR (1992) Hippocampal modulation of acoustic startle and prepulse inhibition in the rat. Pharmacol Biochem Behav 43, 1201-1208.

[29] Bast T, Feldon J (2003) Hippocampal modulation of sensorimotor processes. Prog Neurobiol 70, 319-345.

[30] Castro CA, Hogan JB, Benson KA, Shehata CW, Landauer MR (1995) Behavioral effects of vehicles: DMSO, ethanol, Tween-20, Tween-80, and emulphor-620. Pharmacol Biochem Behav 50, 521-526.

[31] Dutra RC, Claudino RF, Bento AF, Marcon R, Schmidt EC, Bouzon ZL, Pianowski LF, Calixto JB (2011) Preventive and therapeutic euphol treatment attenuates experimental colitis in mice. PLoS One 6, e27122.

[32] Bone RN, Gai Y, Magrioti V, Kokotou MG, Ali T, Lei X, Tse HM, Kokotos G, Ramanadham S (2015) Inhibition of $\mathrm{Ca} 2+$-independent phospholipase A2beta (iPLA2beta) ameliorates islet infiltration and incidence of diabetes in NOD mice. Diabetes 64, 541-554.

[33] Forbes S, Stafford S, Coope G, Heffron H, Real K, Newman R, Davenport R, Barnes M, Grosse J, Cox H (2015) Selective FFA2 agonism appears to act via intestinal PYY to reduce transit and food intake but does not improve glucose tolerance in mouse models. Diabetes 64, 3763-3771.

[34] White KL, Robinson JE, Zhu H, DiBerto JF, Polepally PR, Zjawiony JK, Nichols DE, Malanga CJ, Roth BL (2015) The $\mathrm{G}$ protein-biased kappa-opioid receptor agonist RB-64 is analgesic with a unique spectrum of activities in vivo. $J$ Pharmacol Exp Ther 352, 98-109.

[35] Ji B, Guo W, Ma H, Xu B, Mu W, Zhang Z, Amat A, Cao L (2017) Isoliquiritigenin suppresses IL-1beta induced apoptosis and inflammation in chondrocyte-like ATDC 5 cells by inhibiting NF-kappaB and exerts chondroprotective effects on a mouse model of anterior cruciate ligament transection. Int J Mol Med 40, 1709-1718.

[36] Li ZY, Chung YH, Shin EJ, Dang DK, Jeong JH, Ko SK, Nah SY, Baik TG, Jhoo JH, Ong WY, Nabeshima T, Kim HC (2017) YY-1224, a terpene trilactone-strengthened Ginkgo biloba, attenuates neurodegenerative changes induced by beta-amyloid (1-42) or double transgenic overexpression of
APP and PS1 via inhibition of cyclooxygenase-2. $J$ Neuroinflammation $\mathbf{1 4}, 94$.

[37] Chellian R, Pandy V (2018) Protective effect of alphaasarone against nicotine-induced seizures in mice, but not by its interaction with nicotinic acetylcholine receptors. Biomed Pharmacother 108, 1591-1595.

[38] Ye X, Rong Z, Li Y, Wang X, Cheng B, Cheng Y, Luo H, Ti Y, Huang X, Liu Z, Zhang YW, Zheng W, Zheng H (2018) Protective role of L-3-n-butylphthalide in cognitive function and dysthymic disorders in mouse with chronic epilepsy. Front Pharmacol 9, 734.

[39] Rosen GD, Harry JD (1990) Brain volume estimation from serial section measurements: a comparison of methodologies. J Neurosci Methods 35, 115-124.

[40] Pilz PK, Schnitzler HU (1996) Habituation and sensitization of the acoustic startle response in rats: amplitude, threshold, and latency measures. Neurobiol Learn Mem 66, 67-79.

[41] Knudson IM, Melcher JR (2016) Elevated acoustic startle responses in humans: relationship to reduced loudness discomfort level, but not self-report of hyperacusis. J Assoc Res Otolaryngol 17, 223-235.

[42] Lauer AM, Behrens D, Klump G (2017) Acoustic startle modification as a tool for evaluating auditory function of the mouse: Progress, pitfalls, and potential. Neurosci Biobehav Rev 77, 194-208.

[43] Story D, Chan E, Munro N, Rossignol J, Dunbar GL (2019) Latency to startle is reduced in the 5xFAD mouse model of Alzheimer's disease. Behav Brain Res 359, 823-827.

[44] O'Leary TP, Shin S, Fertan E, Dingle RN, Almuklass A, Gunn RK, Yu Z, Wang J, Brown RE (2017) Reduced acoustic startle response and peripheral hearing loss in the $5 \times \mathrm{XAD}$ mouse model of Alzheimer's disease. Genes Brain Behav 16, 554-563.

[45] Takeuchi H, Iba M, Inoue H, Higuchi M, Takao K, Tsukita K, Karatsu Y, Iwamoto Y, Miyakawa T, Suhara T, Trojanowski JQ, Lee VM, Takahashi R (2011) P301S mutant human tau transgenic mice manifest early symptoms of human tauopathies with dementia and altered sensorimotor gating. PLoS One 6, e21050.

[46] Hartman RE, Wozniak DF, Nardi A, Olney JW, Sartorius L, Holtzman DM (2001) Behavioral phenotyping of GFAPapoE3 and -apoE4 transgenic mice: apoE4 mice show profound working memory impairments in the absence of Alzheimer's-like neuropathology. Exp Neurol 170, 326-344.

[47] Garcia-Mesa Y, Lopez-Ramos JC, Gimenez-Llort L, Revilla S, Guerra R, Gruart A, Laferla FM, Cristofol R, DelgadoGarcia JM, Sanfeliu C (2011) Physical exercise protects against Alzheimer's disease in 3xTg-AD mice. J Alzheimers Dis 24, 421-454.

[48] Esposito L, Raber J, Kekonius L, Yan F, Yu GQ, Bien-Ly N, Puolivali J, Scearce-Levie K, Masliah E, Mucke L (2006) Reduction in mitochondrial superoxide dismutase modulates Alzheimer's disease-like pathology and accelerates the onset of behavioral changes in human amyloid precursor protein transgenic mice. J Neurosci 26, 5167-5179.

[49] Wang H, He J, Zhang R, Zhu S, Wang J, Kong L, Tan Q, Li XM (2012) Sensorimotor gating and memory deficits in an APP/PS1 double transgenic mouse model of Alzheimer's disease. Behav Brain Res 233, 237-243.

[50] Ewers M, Morgan DG, Gordon MN, Woodruff-Pak DS (2006) Associative and motor learning in 12-month-old transgenic APP+PS1 mice. Neurobiol Aging 27, 1118-1128.

[51] Salem LC, Hejl AM, Garde E, Leffers AM, Paulson OB, Waldemar G (2011) White matter hyperintensities and pre- 
pulse inhibition in a mixed elderly population. Psychiatry Res 194, 314-318.

[52] Debette S, Markus HS (2010) The clinical importance of white matter hyperintensities on brain magnetic resonance imaging: systematic review and meta-analysis. BMJ 341, c3666.

[53] Gordon BA, Najmi S, Hsu P, Roe CM, Morris JC, Benzinger TL (2015) The effects of white matter hyperintensities and amyloid deposition on Alzheimer dementia. Neuroimage Clin 8, 246-252.

[54] Kandel BM, Avants BB, Gee JC, McMillan CT, Erus G, Doshi J, Davatzikos C, Wolk DA (2016) White matter hyperintensities are more highly associated with preclinical Alzheimer's disease than imaging and cognitive markers of neurodegeneration. Alzheimers Dement (Amst) 4, 18-27.

[55] Braff DL, Geyer MA (1990) Sensorimotor gating and schizophrenia. Human and animal model studies. Arch Gen Psychiatry 47, 181-188.

[56] Swerdlow NR, Weber M, Qu Y, Light GA, Braff DL (2008) Realistic expectations of prepulse inhibition in translational models for schizophrenia research. Psychopharmacology (Berl) 199, 331-388.

[57] Ludewig K, Geyer MA, Vollenweider FX (2003) Deficits in prepulse inhibition and habituation in never-medicated, first-episode schizophrenia. Biol Psychiatry 54, 121-128.

[58] Grillon C, Morgan CA, Southwick SM, Davis M, Charney DS (1996) Baseline startle amplitude and prepulse inhibition in Vietnam veterans with posttraumatic stress disorder. Psychiatry Res 64, 169-178.

[59] Swerdlow NR, Paulsen J, Braff DL, Butters N, Geyer MA, Swenson MR (1995) Impaired prepulse inhibition of acoustic and tactile startle response in patients with Huntington's disease. J Neurol Neurosurg Psychiatry 58, 192-200.

[60] Shoji H, Miyakawa T (2018) Relationships between the acoustic startle response and prepulse inhibition in C57BL/6J mice: a large-scale meta-analytic study. Mol Brain 11, 42.

[61] Hejl AM, Glenthoj B, Mackeprang T, Hemmingsen R, Waldemar G (2004) Prepulse inhibition in patients with Alzheimer's disease. Neurobiol Aging 25, 1045-1050.

[62] Zhang WN, Bast T, Feldon J (2002) Prepulse inhibition in rats with temporary inhibition/inactivation of ventral or dorsal hippocampus. Pharmacol Biochem Behav 73, 929-940.
[63] Padurariu M, Ciobica A, Mavroudis I, Fotiou D, Baloyannis S (2012) Hippocampal neuronal loss in the CA1 and CA3 areas of Alzheimer's disease patients. Psychiatr Danub 24, 152-158.

[64] Lipska BK, Swerdlow NR, Geyer MA, Jaskiw GE, Braff DL, Weinberger DR (1995) Neonatal excitotoxic hippocampal damage in rats causes post-pubertal changes in prepulse inhibition of startle and its disruption by apomorphine. Psychopharmacology (Berl) 122, 35-43.

[65] Willott JF, Tanner L, O'Steen J, Johnson KR, Bogue MA, Gagnon L (2003) Acoustic startle and prepulse inhibition in 40 inbred strains of mice. Behav Neurosci 117, 716-727.

[66] Shoji H, Takao K, Hattori S, Miyakawa T (2016) Agerelated changes in behavior in $\mathrm{C} 57 \mathrm{BL} / 6 \mathrm{~J}$ mice from young adulthood to middle age. Mol Brain 9, 11 .

[67] Varty GB, Powell SB, Lehmann-Masten V, Buell MR, Geyer MA (2006) Isolation rearing of mice induces deficits in prepulse inhibition of the startle response. Behav Brain Res 169, 162-167.

[68] Fodor A, Klausz B, Toth B, Zelena D (2016) The prepulse inhibition deficit appearance is largely independent on the circadian cycle, body weight, and the gender of vasopressin deficient Brattleboro rat. Endocr Regul 50, 16-23.

[69] Ouagazzal AM, Reiss D, Romand R (2006) Effects of agerelated hearing loss on startle reflex and prepulse inhibition in mice on pure and mixed C57BL and 129 genetic background. Behav Brain Res 172, 307-315.

[70] Bouter Y, Kacprowski T, Weissmann R, Dietrich K, Borgers $\mathrm{H}$, Brauss A, Sperling C, Wirths O, Albrecht M, Jensen LR, Kuss AW, Bayer TA (2014) Deciphering the molecular profile of plaques, memory decline and neuron loss in two mouse models for Alzheimer's disease by deep sequencing. Front Aging Neurosci 6, 75.

[71] Alexandru A, Jagla W, Graubner S, Becker A, Bauscher C, Kohlmann S, Sedlmeier R, Raber KA, Cynis H, Ronicke R, Reymann KG, Petrasch-Parwez E, Hartlage-Rubsamen M, Waniek A, Rossner S, Schilling S, Osmand AP, Demuth HU, von Horsten S (2011) Selective hippocampal neurodegeneration in transgenic mice expressing small amounts of truncated Abeta is induced by pyroglutamate-Abeta formation. J Neurosci 31, 12790-12801. 